\title{
AVAILABILITY OF LABORATORY SUPPORTING STAFF AND ITS EFFECT ON THE CONDUCT OF BIOLOGY PRACTICAL LESSON AMONG PUBLIC SECONDARY SCHOOLS IN SOKOTO STATE, NIGERIA
}

\section{SHAMSUDEEN BELLO}

\begin{abstract}
The study has investigated availability of laboratory supporting staff and its effect on the conduct of biology practical lesson among public secondary schools in Sokoto State, Nigeria. The study answered two research questions and one hypothesis. The population of the study comprised 32 senior secondary schools in Sokoto metropolis with 93 biology teachers. Fifteen (15) public secondary schools were randomly selected with 30 biology teachers as sampled teachers, including heads of biology departments. The study used an instrument titled Biology Laboratory Practical Work Questionnaire (BLPWQ) with reliability coefficient of 0.82 . Data obtained from the field were analyzed using simple descriptive statistics and chi-square. The findings revealed that public schools in Sokoto metropolis have no sufficient laboratory supporting staff. The schools also conduct little practical lessons. Similarly, there was significant relationship between laboratory supporting staff availability and frequency of conduct of biology practical lessons. It's recommended that, the government should provide adequate and qualified laboratory supporting staff (laboratory assistant, technician/attendant) to the secondary schools in the state.
\end{abstract}

\section{Introduction}

Laboratory supporting staff are often officially designed as Laboratory Assistants/ Attendants/Technicians, who are allied to biology teachers. They play a complementary role in the teaching carried out especially during practical work. They also interact and coordinate, with teaching staffs information about the experiment/demonstrations conducted in laboratories. The information here are: type of activity (experiment/demonstration), number of students, requirements for experiments, chemicals/materials needed, preparation to be made by the laboratory staff etc.

Under close supervision, laboratory supporting staff perform routine and semi-skilled work in the collection, preparation and distribution of field samples, maintenance of laboratory equipment and glassware. Other activities carried out regularly by laboratory supporting staff, according to Consortium of Local Education Authorities for the Provision of Science Services, CLEAPSS (2009) include, making up solutions, assembling apparatus, delivering equipment to rooms, collecting, checking and returning equipment to stores and disposing of waste materials, Taking care of laboratory equipment and apparatus, carrying out maintenance and repair of equipment, stocktaking of chemicals and/or equipment, obtaining materials by local purchase, placing orders and checking deliveries or invoices.

The operation of laboratories in schools is a very big task for teachers. The skills required are not normally possessed by most teachers, and this is not a task that can be safely and efficiently carried out by an untrained person (Gleadall, and Griffiths, 2007). 
A science laboratory assistant/attendant/technician, therefore, has an essential role to play in the current and future science education. They have considerable skill and expertise not available to science teachers. Trained and experienced laboratory assistants/ attendants/technicians have detailed knowledge of practical techniques and, often, greater expertise (than do the science teachers) in matters of techniques, safety, efficiency and economy of apparatus. Experienced and skilled laboratory supporting staff can give direct support to practical activities, offering technical advice to students and staff, and rectifying problems. They can have an effect on the resources used by the department by ensuring that a wide range of apparatus and materials are available, appropriately maintained and stored effectively. They do not only contribute to the safety and efficiency of the department, but also enable teachers to offer varied and stimulating science lessons.

The importance of practical work to better understanding of science is paramount to development of scientific process skills in students. Lunetta, Hofstein, and Clough ( 2007) define practical work as learning experiences in which students interact with materials or with secondary sources of data to observe and understand the natural world (for example: aerial photographs to examine lunar and earth geographic features; spectra to examine the nature of stars and atmospheres; solar images to examine living systems). Practical work according to Gangoli (1995) promotes long term memory in students, enhances pupils developments of the ethical dimensions of science, instills the spirit of collaboration and active participation among learners, exposes learners to scientific experience that could ultimately help them in developing scientific attitudes and skills.

Shaibu and Mari (2008), in a paper titled Enriching Laboratory Activities in Schools, revealed that laboratory activities stimulate the acquisition of both manipulative and cognitive skills by learners. They observed that laboratory activities in most schools, do not allow learners to carry out investigation that involves designing experiments, making observations, collecting and interpreting data, to think and evolve solution to problem. Bajah (1984) stated that there is abundant research evidence to support the view that when science is taught through the medium of practical work, a lot of enjoyable learning takes place. Recall of information has been found to be easier when the information to be recalled had initially been presented through a practical approach.

Ughamadu (1992) stated that creative use of equipment in teaching science increases the probability that students will learn and improve their performance. Abimbade (1999) attested that instructional or laboratory materials when appropriately used, enhance learning, improve the competence of teachers and make learning more meaningful to learners. He added that, on the other hand, when these materials are misused, sequel to lack of knowledge on how to use them, science teaching and learning process may be adversely affected. Jatau and Jatau (2008) reported that when instructional equipment are appropriately utilized, they bring about more effectiveness in teaching and learning process, but this depends on teacher's ability to use them efficiently. Edet and Inyang (2008) revealed that students taught with ecological garden (outdoor laboratory) performed better than those taught without ecological garden. This is because students were taught directly from natural objects with the help of equipment of ecological studies. 
It is clear that practical work is essential in the development of scientific understanding among students, can increase their interest in science and can contribute to improved examination results. Technicians have a key role to play, enabling teachers to teach exciting and varied practicals in an efficient and safe environment. Sir Roberts cited in (Cleapss, 2009) reported that: "Pupils' learning experiences are influenced not just by the teacher but also by the environment in which the subjects are taught. He identified three factors that are responsible and important to include: The quality of the laboratory and associated scientific and technical equipment, the support provided by laboratory technicians and, lastly, the support and guidance that pupils have in carrying out practical work (with particular reference to the adverse effect of high pupil-to-teacher ratios)". According to him, technicians contribute to all of these three factors by providing and caring for laboratories \& equipment and for the advice and guidance they give to teachers and pupils. Hence, the role of laboratory supporting staff is enormous for conducting successful practical work.

\section{Statement of the problem}

Practical work/lesson is of paramount importance in the development and performance of students in science. Several researches and reports have revealed the need for effective practical lessons using appropriate equipment. For example, the Chief Examiners' Reports of the West African Examinations Council (WAEC) from 2005 to 2012 indicated poor performance of students in biology practical examinations. Yet many science teachers tend to avoid organizing practical lessons to their students. Some of the reasons for poor performance of students in examinations include poor science teaching due to teacher's incompetence and none availability of laboratory equipment, hence the need for this study.

\section{Objective of the study}

The aim of this study was to investigate availability of laboratory supporting staff and its effect on the conduct of practical lessons among secondary schools in Sokoto metropolis. In doing so, the study had the following objectives:

i. To determine available laboratory supporting staff among public secondary schools in Sokoto State

ii. To establish the relationship between availability of laboratory supporting staff and conduct of biology practical lessons in secondary schools.

\section{Research Questions}

In the process of investigating availability of laboratory supporting staff and its effect on the conduct of practical lessons among secondary schools in Sokoto, the following research questions were raised.

i. Are there laboratory supporting staff available in public secondary schools in Sokoto metropolis?

ii. Is there any relationship between laboratory supporting staff availability and frequency of conduct of biology practical lesson? 


\section{Research Hypothesis}

i. There was no significant relationship between laboratory supporting staff availability and frequency of conduct of biology practical lessons.

\section{Methodology}

Research methodology used in this study was briefly discussed under the following headings.

\section{Research Design}

The research design used in this study was sample survey research design. The researcher chose this method because survey research is useful in describing the characteristics of a large population; very large samples are feasible, making the results statistically significant even when analyzing multiple variables.

\section{Population}

The population of this study comprised 32 senior secondary schools in Sokoto metropolis. These included schools from Science and Technical Education Board, Arabic and Islamic Education Board, Teachers' Service Board and Federal Ministry of Education. The schools had a population of 93 biology teachers.

\section{Sample}

The researcher selected fifteen (15) secondary schools out of the whole population in Sokoto metropolis using random sampling techniques. This represented 46.9 percent of the populations. Head of biology department and one other biology teacher from each selected schools were chosen to represent the population of teachers, which represented 33.0 percent of the teachers' population. This was as recommended by Gay (1981), that a sample of $20 \%$ is the minimum, if the population is small.

\section{Instrumentation}

The instrument used in this study was Biology Laboratory Practical Work Questionnaire (BLPWQ). It was designed for biology teachers of the selected schools. The aim of the instrument was to find out availability of laboratory supporting staff and the conduct of practical lesson among secondary schools. The instrument had two sections, A and B. Section A inquired about general information of the respondents including qualifications and years of teaching experience. While section B consisted of twelve items which sought information on the availability of laboratory supporting staff and the conduct of practical lessons among secondary schools. The instrument was validated by experienced biologists and biology teachers in both secondary schools and tertiary institutions in Sokoto State. The reliability index of questionnaire was obtained using test-retest method, after a pilot study with six teachers. The reliability index 0.80 was obtained using Pearson Product Moment Correlation as a statistical tool. 


\section{Analysis of Data}

Data collected were analysed using simple descriptive statistics and chi-square. Frequency counts were used to determine availability of laboratory supporting staff. On the other hand, chi-square calculation was done to analyse the relationship between availability of supporting staff and frequency conduct of biology practical lessons at 0.05 level of significance.

\section{Results and discussion}

Table 1: Availability of laboratory supporting staffs in biology laboratories

\begin{tabular}{lccc}
\hline S/No. & School Code & Available \& Qualified & Available Not Qualified \\
\hline 1. & A & 0 & 0 \\
2. & B & 0 & 0 \\
3. & C & 1 & 0 \\
4. & D & 0 & 0 \\
5. & E & 0 & 1 \\
6. & F & 0 & 0 \\
7. & G & 1 & 0 \\
8. & H & 0 & 1 \\
9. & I & 0 & 0 \\
10 & J & 0 & 1 \\
11. & K & 0 & 0 \\
12 & L & 0 & 1 \\
13 & M & 0 & 0 \\
14 & N & 0 & 0 \\
15 & O & 0 & 0 \\
\hline
\end{tabular}

Information from Table 1 above shows that two (2) schools have qualified laboratory supporting staff, four (4) schools have unqualified laboratory supporting staffs while; nine (9) schools reported that they have no supporting staff in their biology laboratories. This revealed that $13.3 \%$ have qualified laboratory supporting staff, 26.6 have unqualified laboratory supporting staff while $60.1 \%$ have no laboratory supporting staff.

Table 2: $\quad$ Biology periods and conduct of practical work per term

\begin{tabular}{lllllll}
\hline S/no. & School code & $\begin{array}{l}\text { Lab. Supporting } \\
\text { staff availability }\end{array}$ & $\begin{array}{l}\text { No of } \\
\text { periods/term }\end{array}$ & $\begin{array}{l}\text { No. Practical/ } \\
\text { term for each } \\
\text { class }\end{array}$ & $\begin{array}{l}\% \\
\text { practical/ } \\
\text { term for each } \\
\text { class }\end{array}$ \\
\hline 1. & A & 0 & & & $5.0 \%$ \\
2. & $\mathrm{~B}$ & 0 & 40 & 2 & $2.5 \%$ \\
3. & $\mathrm{C}$ & 1 & 40 & 1 & $15.0 \%$ \\
4. & $\mathrm{D}$ & 0 & 40 & 6 & $5.0 \%$ \\
5. & $\mathrm{E}$ & 1 & 40 & 2 & $12.5 \%$ \\
6. & $\mathrm{~F}$ & 0 & 40 & 5 & $5.0 \%$ \\
7. & $\mathrm{G}$ & 1 & 40 & 2 & $12.5 \%$ \\
8. & $\mathrm{H}$ & 1 & 40 & 5 & $12.5 \%$ \\
\hline
\end{tabular}




\begin{tabular}{llllll}
\hline 9. & $\mathrm{I}$ & 0 & 40 & 1 & $2.5 \%$ \\
10 & $\mathrm{~J}$ & 1 & 40 & 4 & $10.0 \%$ \\
11. & $\mathrm{~K}$ & 0 & 40 & 1 & $2.5 \%$ \\
12 & $\mathrm{~L}$ & 0 & 40 & 1 & $2.5 \%$ \\
13 & $\mathrm{M}$ & 0 & 40 & 1 & $2.5 \%$ \\
14 & $\mathrm{~N}$ & 0 & 40 & 1 & $2.5 \%$ \\
15 & $\mathrm{O}$ & 0 & 40 & 1 & $2.5 \%$ \\
\hline
\end{tabular}

The analysis from Table 2 above shows that all schools allocate 4 periods for biology lessons every week and 40 periods for the ten weeks of normal teaching in a term. The table further revealed that the highest number of periods used for the conduct of practical lesson per term is 6 which represents $15 \%$ of the total number of periods. On the other hand, the lowest number of practical lessons per term from the table is 1 which represents $2.5 \%$ of the periods. Also from the analysis only four schools conduct practical lessons five times and above while eleven schools conduct practical lessons less than five times in a term. It can be observed also from the table that schools with higher percentages of practical lessons per term are those with laboratory supporting staff.

Table 3: Chi-square result on hypothesis 1

\begin{tabular}{lllll}
\hline Df & $\mathrm{X}^{2}$ cal & $\mathrm{X}^{2}$ critical & Significant value & $\mathrm{P}$ value cal. \\
\hline 1 & 5.45 & 3.54 & 0.05 & 0.02
\end{tabular}

The result in Table 3 above shows result of chi-square analysis on availability of laboratory supporting staff and frequency conduct of biology practical work in schools. From the Table, $\mathrm{X}^{2}$ - calculated is 5.45 while $\mathrm{X}^{2}$ - critical from the distribution table is 3.54 at 0.05 level of significance and degree of freedom 1 . This means that $X^{2}$ - calculated is higher than $X^{2}$ critical, as a result the hypothesis is then rejected, indicating there is significant relationship between laboratory supporting staff availability and frequency of conduct of practical lesson in secondary schools. The Table further revealed that $p$ value is 0.02 which is less than the significant value $(\mathrm{p}<0.05)$. This also confirmed significant relationship between laboratory supporting staff availability and frequent conduct of practical lesson in secondary schools.

\section{Discussions}

\section{Availability of laboratory supporting staff}

The analysis from Table 1 revealed that only six schools have laboratory supporting staff, among which two schools have qualified staff which is equivalent to $13.3 \%$ (having certificate in laboratory science), four schools have unqualified laboratory supporting staff, representing $26.6 \%$. On the other hand nine schools $(60.1 \%)$ reported that they have no supporting staff in their biology laboratory.

In an oral interview some teachers reported that they often used their colleagues in their conduct of practical lesson, some stated they had to convert other non teaching staff as laboratory supporting staff to assist in cleaning and arranging equipment before and after practical lesson. 


\section{Conduct of practical lesson}

The analysis from Table 2 above shows that all public schools in Sokoto metropolis allocate 4 periods for biology lessons every week and 40 periods for the whole term. The table further revealed that the highest number of periods used for the conduct of practical lesson per term is 6 which represent $15.0 \%$ of the total number of periods. On the other hand, the lowest number of practical lessons per term according to the table is 1 which represents $2.5 \%$ of the periods. Also from the analysis only four (4) schools conduct practical lessons five times and above in a term, while eleven (11) schools conduct practical less than five times in a term. When asked in an interview, on the factors affecting regular practical lesson the teachers said some of the factors responsible for this were insufficient laboratory space, and laboratory equipment, non availability or inadequate laboratory supporting staff.

\section{Relationship between availability of laboratory supporting staff and Conduct of practical lesson}

The hypothesis tested in this instance proposed that there is no significant relationship between laboratory supporting staff availability and frequency of conduct of biology practical lesson. From the results in Table 3, the chi-square calculated is higher than chisquare critical, which leads to rejection of the hypothesis and implies that there is significant relationship between laboratory supporting staff availability and frequent conduct of biology practical lesson. This finding was in line with that of Sir Roberts cited in (CLEAPSS, 2009) who reported that: "Pupils' learning experiences were influenced not just by the teacher but also by the environment in which the subjects are taught and identified the support provided by laboratory technicians among the three factors responsible for successful practical lessons. He further revealed that those activities carried out regularly by most laboratory supporting staff are very important in the conduct of practicals.

\section{Recommendation}

Based on the findings of this study, the following recommendations were made;

i. The government should provide adequate and qualified laboratory supporting staff (laboratory assistant, technician/attendant) to the secondary schools in the state.

ii. School principals should leased with biology teachers to train some supporting staff in the school and provide them with laboratory skills, to work as supporting staff when the need arise.

iii. Biology teachers should try as much as possible to increase the number of practical lessons they conduct per term in their schools. 


\section{Conclusion}

It can be said that for any successful biology practical lesson, there is the need for laboratory supporting staff. This study found that public schools in Sokoto metropolis have no sufficient laboratory supporting staff and as a result conduct little practical lessons. Similarly, there was significant relationship between availability laboratory supporting staff and frequency of conduct of biology practical lessons.

\section{Reference}

Abimbade A. (1999). Principles and Practice of Educational Technology, Ibadan: International publishers limited

Bajah, S. T. (1984). Continuous Assessment and Practical Work in Science Teaching: A plea for pragmatism. Journal of STAN, 20 (2): 43-48.

Cleapss, (2009) Technicians and their jobs, G228 retrieved at www.cleapss.org.uk on $18^{\text {th }}$ March, 2015, at 16:34.

Edet, B. U. \& Inyang, G. J. (2008). Effect of Environmental Resources on Students Achievement in Biology: $49^{\text {th }}$ STAN Annual Conference Proceedings.

Gangoli, S. D. 1995: A study of the effectiveness of the guided open-ended Approach to physics Experiments. International Journal of Science Education, 17 (2): 233-241.

Gleadall, G. \& Griffiths, J. (2007). Science Technical Staff in Schools: Staffing and Conditions of Laboratory technicians. Association of Victoria ABN 96439156002 retrieved at www.Itav.org.au on $14^{\text {th }}$ March, 2015 at 15:42.

Jatau, A. A. \& Jatau, S. Y. (2008). Identification of Level of Utilization of Instructional Resources among Science Teachers in Pankshin: STAN 49 ${ }^{\text {th }}$ Annual Conference Proceedings.

Lunetta, V. N.; Hofstein, A. \& Clough, M. P. (2007). Teaching and learning in the school science laboratory: An Analysis of Research, Theory, and Practice. In Handbook of Research on Science Education (ed. S K Abell and N. G. Lederman), pp. 393-431. Mahwah, NJ: Lawrence Erlbaum Associates.

Shaibu, A. M. \& Mari J. S. (2008). Enriching Laboratory Activities in School: Implication for the Chemistry Teachers: $41^{\text {st }}$ STAN Annual Conference Proceedings, 146-148.

Tsui, K. T. (1998). Understanding teacher performance towards a comprehensive frame work: Asia Pacific Journal of Teacher Education and Development, 1 (2): 81-89.

Ughamadu, K. A. (1992). Curriculum Concept, Development and Implementation: Onitsha: Emba publishing Company ltd. 